\title{
Tubes of deep sea hydrothermal vent worms Riftia pachyptila (Vestimentifera) and Alvinella pompejana (Annelida)
}

\author{
F. Gaill ${ }^{1} \&$ S. Hunt ${ }^{2}$ \\ ${ }^{1}$ CNRS Centre de Biologie Cellulaire, 67 Rue Maurice Gunsbourg, 94200 Ivry sur Seine, France \\ ${ }^{2}$ Department of Biological Sciences, University of Lancaster, Bailrigg, Lancaster LA1 4YQ, England
}

\begin{abstract}
The aim of this study was to compare the structure and chemistry of the dwelling tubes of 2 invertebrate species living close to deep sea hydrothermal vents at $12^{\circ} 48^{\prime} \mathrm{N}, 103^{\circ} 56^{\prime} \mathrm{W}$ and $2600 \mathrm{~m}$ depth and collected during April 1984. The Riftia pachyptila tube is formed of a chitin proteoglycan/ protein complex whereas the Alvinella pompejana tube is made from an unusually stable glycoprotein matrix containing a high level of elemental sulfur. The A. pompejana tube is physically and chemically more stable and encloses bacteria within the tube wall material.
\end{abstract}

\section{INTRODUCTION}

The Pompeii worm Alvinella pompejana, a polychaetous annelid, and Riftia pachyptila, previously considered as pogonophoran but now placed in the putative phylum Vestimentifera (Jones 1985), are found at a depth of $2600 \mathrm{~m}$ around deep sea hydrothermal vents. $R$. pachyptila lives where the vent water (anoxic, rich in hydrogen sulphide, temperatures up to $15^{\circ} \mathrm{C}$ ) mixes with surrounding seawater (oxygenated, no hydrogen sulphide, $2^{\circ} \mathrm{C}$ ) (Arp \& Childress 1981) while $A$. pompejana forms incrustations on the white smokers closer to the hot spring, by secreting mineralised organic tubes and inhabiting zones of active mixing of hot, reducing, acidic, metal-rich, fluid with cold, well-oxygenated seawater (Desbruyères et al. 1983). Here, within a few decimeters, the temperature changes from $200^{\circ} \mathrm{C}$ to $18^{\circ} \mathrm{C}$.

Both species live in the tubes they secrete. These tubes have been analyzed in a morphological and biochemical way to see if the original location of these species may have an influence on their tube characteristics.

\section{MATERIALS AND METHODS}

Tubes from both worms, Alvinella pompejana and Riftia pachyptila, were collected at $2600 \mathrm{~m}$ depth by the submersible Cyana in April 1984 during the Biocyarise cruise $\left(12^{\circ} 48^{\prime} \mathrm{N}, 103^{\circ} 56^{\prime} \mathrm{W}\right)$. Tubes were preserved in alcohol, or fixed in formol-saline, or simply rinsed and air-dried.

Some pieces of tubes were post-fixed with osmium tetroxide ( $1 \%$ final concentration) and embedded in Durcupan. Thin sections were stained with aqueous uranyl acetate and lead citrate and examined using a Phillips EM 201 TEM at the Centre de Biologie Cellulaire, CNRS, Ivry (France).

Scanning electron microscope (SEM) observations were made on fixed samples, dehydrated with ethanol, critical-point dried and sputter coated with gold. Samples were examined using a Phillips 505 SEM at the Centre de Biologie Cellulaire Ivry (France).

Neutral hexose was determined using the orcinolsulphuric acid method (Barker et al. 1963).

Amino acid analyses were performed on unfixed samples hydrolysed in $3 \mathrm{M}$ methanesulfonic acid for $48 \mathrm{~h}$ at $105^{\circ} \mathrm{C}$, in vacuo. Hydrolysates were brought to starting $\mathrm{pH}(2.0)$ with sodium hydroxide and analysed using an LKB 4101 analyser.

Elemental compositions were determined either using a Phillips PW1400 X-ray fluorescence spectrometer in the Department of Environmental Sciences at Lancaster or using the Lancaster Biological Sciences Department Jeol JSM50A scanning electron microscope X-ray microprobe analyser with Kevex detection and Link Systems data processing. Probe spots of $1 \mathrm{~cm}^{2}$ 
were applied at $\times 100$ magnification. Samples were either analysed whole after a brief wash in distilled water and drying or as powdered ash produced by heating at $500^{\circ} \mathrm{C}$ in air for 24 h.

Chitin contents were determined gravimetrically after removal of protein at $105^{\circ} \mathrm{C}$ in $1 \mathrm{M}$ potassium hydroxide for $24 \mathrm{~h}$ (Hunt \& Nixon 1981). Elemental sulphur was extracted from dry material by repeated extraction with either spectroscopic grade carbon disulphide or $\mathrm{n}$-hexane and the content determined gravimetrically. The identity and purity of the sulphur extracted was established by X-ray microprobe analysis and (in the Chemistry Department at Lancaster) by mass spectrometry on a Hewlett-Packard 5995 GC/MS, with direct entry probe.

Thermal transitions were measured on $1 \mathrm{~mm} \times$ $5 \mathrm{~mm}$ specimens, of established orientation relative to tube geometry, held lightly in a $1 \mathrm{~mm}$ gap between optical quality quartz plates which formed a cell containing $50 \%$ glycerol in distilled water. This cell was supported in a water bath containing a heater, thermostat and digital thermocouple thermometer. Thermal transitions were observed, using a cathetometer, through the glass wall of the bath.

Swelling and shrinkage estimations of chemical stability were made on samples, similar to those used for thermal transition measurements, held in slots in shallow baths on the stage of a travelling microscope.

The range and molecular weights of solubilizable protein in the tubes was determined, after solubilization in $2 \%$ SDS pH 6.8 Tris/glycine treatment buffer, by slab SDS polyacrylamide gel electrophoresis (SDSPAGE). Samples (1 mg) were triturated with a small volume of solubilization buffer, heated at $100^{\circ} \mathrm{C}$ for $15 \mathrm{~min}$, centrifuged and applied to $10 \%$ gels, in an LKB slab gel-electrophoresis apparatus, using $20 \mathrm{~mA}$ $\mathrm{cm}^{-1}$ for $4 \mathrm{~h}$ in $\mathrm{pH} 8.3,2 \%$ SDS-Tris/glycine running buffer. Staining was with Kenacid Blue. Molecular weights were estimated by comparison with mobilities of protein standards of known molecular weight.

\section{RESULTS AND DISCUSSION}

The cylindrical, virtually straight, tubes of Riftia pachyptila can achieve $2 \mathrm{~m}$ or more length $15 \mathrm{~cm}$ diameter, $2 \mathrm{~mm}$ wall thickness). The Alvinella pompe- jana tube is tortuous and smaller $(10 \mathrm{~cm}$ length, $1.5 \mathrm{~cm}$ in diameter, $1 \mathrm{~mm}$ thickness). Both tube walls are concentrically multilayered (Fig. $1 \mathrm{~B} \& 2 \mathrm{~B}$ ). The A. pompejana tube is fibrous (Fig. 1B) and appears to be made of successive fibril layers disposed as in plywood. In each layer, fibrils are parallel but their orientation varies from one layer to the successive one in a discontinuous way (Fig. 1D). The fibril orientation varies through the whole tube thickness, giving an irregular pattern of fibril section rows (Fig, 1C, D). Sinusoidal patterns are observed where irregular series of nested arcs may be recognized in semi-thin sections (Fig. 1C). Such patterns are not detected in the tube of R. pachyptila. A fibrillar aspect does appear in the $R$. pachyptila tube at high magnification, where opaque fibrillar layers alternate with electron-light ones (Fig. 2D).

Filamentous bacteria associate with the inner surface of the Alvinella pompejana tube (Fig. 1A, D). Numbers of these bacteria $(50 \mu \mathrm{m}$ long, $2.5 \mu \mathrm{m}$ diameter) vary from region to region of the same tube, rodshape bacteria often being present also. Numerous bacteria are enclosed inside the tube of $A$. pompejana (Fig. $1 C \& 2 A, C$ ). In contrast, only a few non-filamentous (45 nm diameter) bacteria occur in the Riftia pachyptila tube outer surface (Fig. 2B).

Structurally dissimilar, the tubes of the 2 worms are also compositionally unalike. Inorganic content of the Riftia pachyptila tube is low $(3.0 \%$ ash) but that of Alvinella pompejana high (29\% ash). Extraction of $A$. pompejana tube with carbon disulphide yielded 12 to $25 \%$ of free elemental sulfur. Some elemental sulfur has been found in mucus accumulations associated with another hydrothermal polychaete species, Paralvinella sp. (Juniper et al. in press).

This elemental sulfur in the Alvinella pompejana tube may come from the bacteria it encloses, as bacteria have been implicated as a source of elemental sulfur in clam gill (Vetter 1985). Epibiotic bacteria have been described at the dorsal surface of $A$. pompejana (Gaill et al. 1984) and on the tube inner surface (Desbruyères et al. 1985); this is the first time they have been recorded within wall material. We know neither the origin of these latter bacteria, nor their metabolism type. One hypothesis is that as the tube inner surface is covered by a high density of bacteria, newly secreted tube material from the epidermis will capture bacteria, enclosing then in the wall. Such a process will not

Fig. 1. Alvinella pompejana tube. (A) Scanning electron micrograph (SEM) of filamentous bacteria from the inner surface of the tube $(\times 6000)$. (B) The tube is made of superimposed layers (transverse section, SEM $\times 100$ ). (C) Oblique semi-thin sections of the tube; 3 layers of bacteria (b) are enclosed between the fibril layers ( $\mathrm{r}$ ), fibril sections display sinusoidal patterns, which look like irregular inversed nested arcs (a) $(\times 150)$. (D) Filamentous bacteria (b) associated with the inner surface of the tube. A fibrillar structure is detected inside the tube (t). Fibril sections are parallel in each row ( $\mathrm{r}$ ) which are parallel with the tube surface (s) (semi-thin section, $\times 600)$. (E) The tube is made of successive layers of parallel fibrils $(1,2,3)$. Fibril orientation varies from one layer to the successive one in a discontinuous way $(\mathrm{SEM} \times 1700)$ 

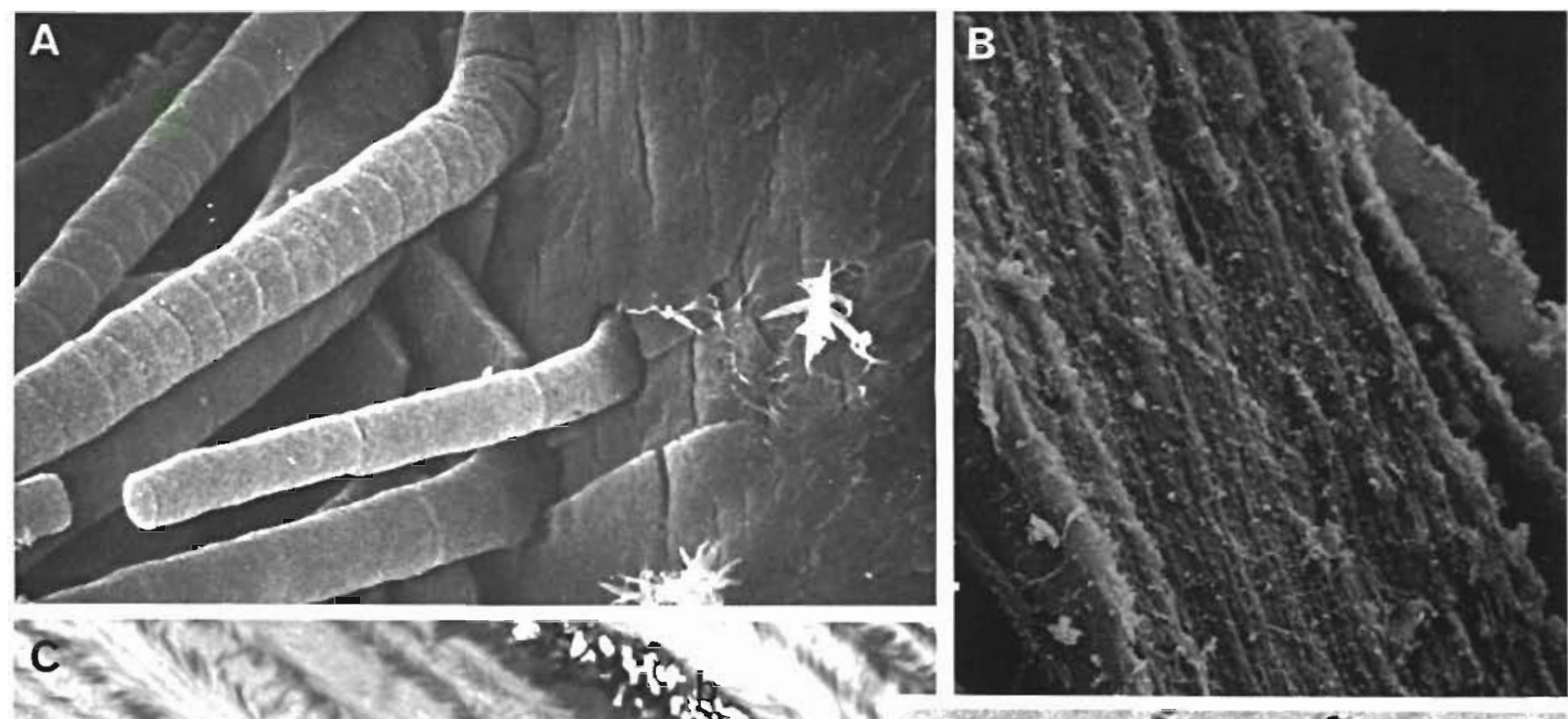

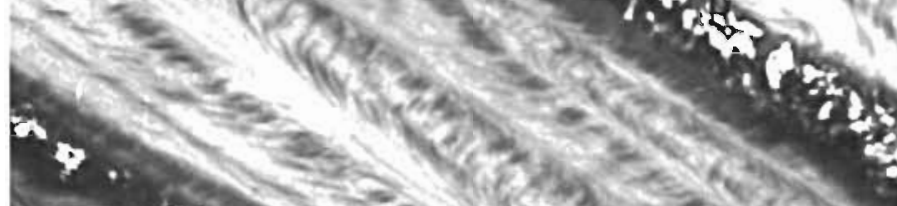

a... $\sim b$ b.

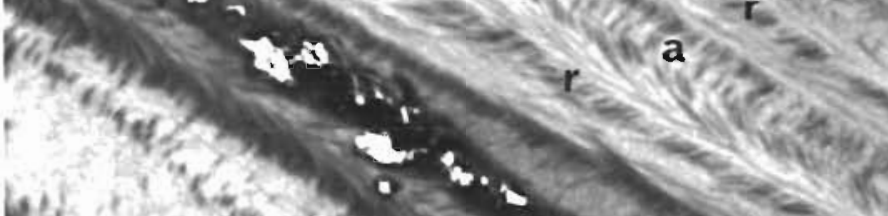

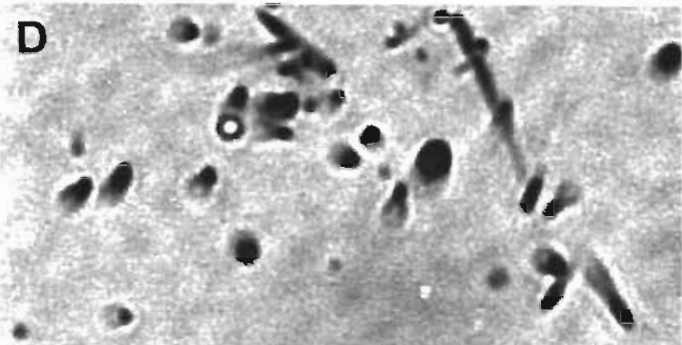

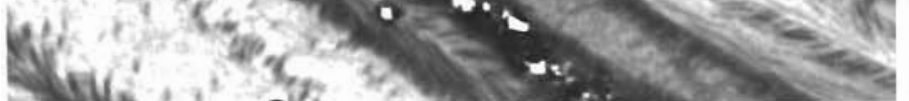

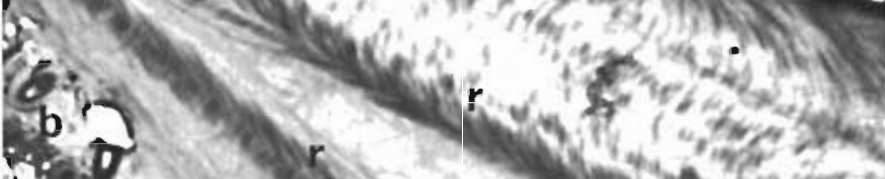

in. 0 .

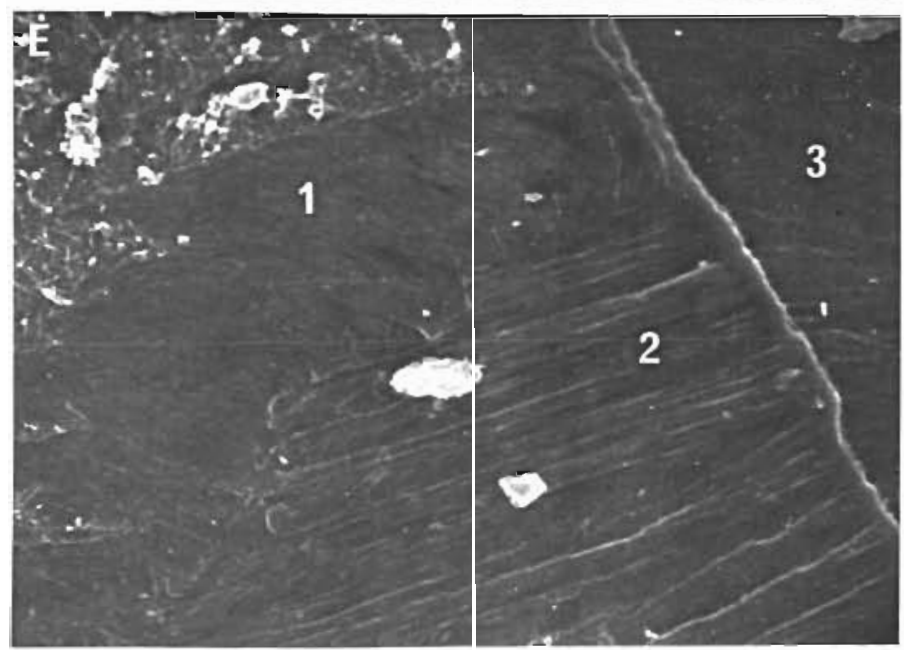

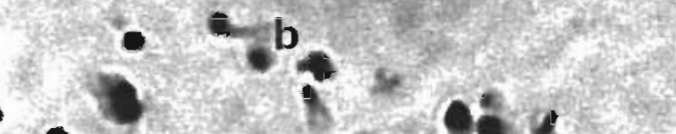

-e 40.92

- 4.

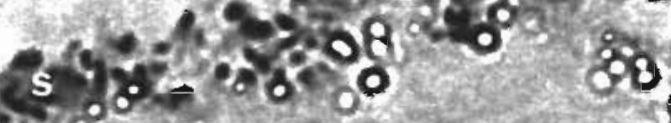

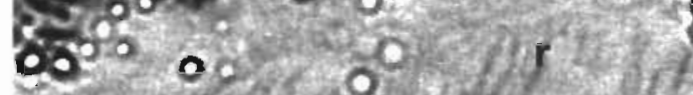

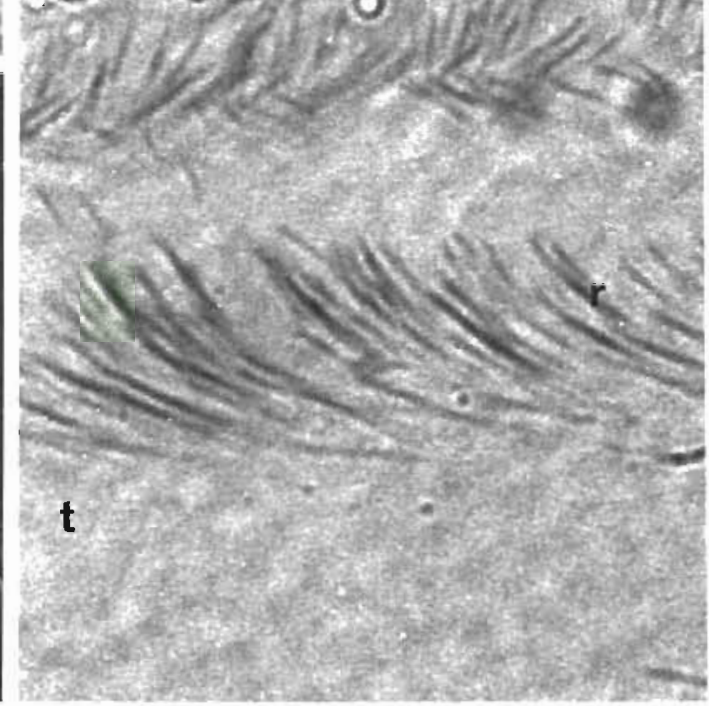


occur in Riftia pachyptila where the bacteria are endosymbiotic (Cavanaugh et al. 1981).

The Riftia pachyptila tube contains no free sulfur. Elements identified by X-ray fluorescence and X-ray microprobe are given in Table 1. Microscopically, $R$. pachyptila tubes seem relatively uncontaminated by detritus, while Alvinella pompejana tubes incorporate
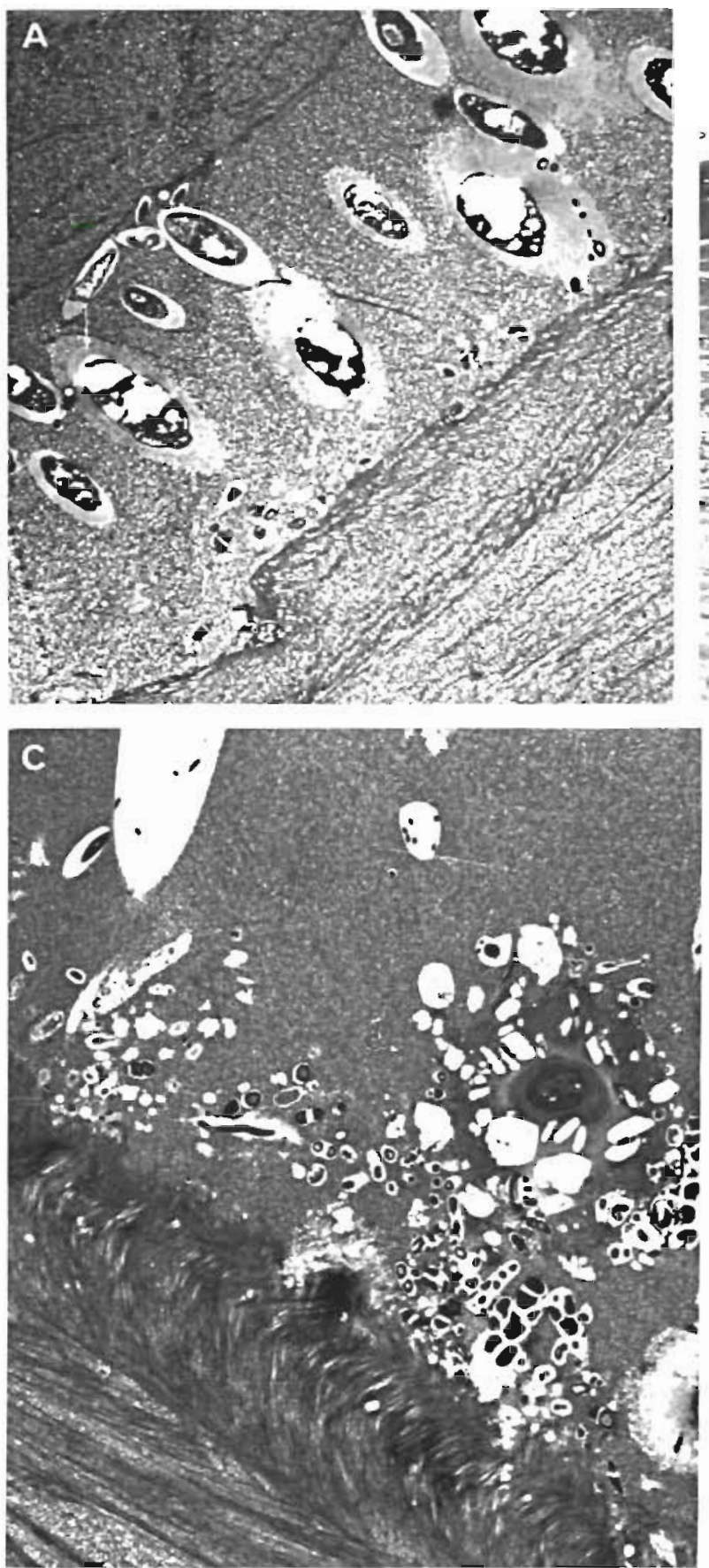

quantities of granular particulate material. X-ray tomography suggests that some of this is crystalline iron and zinc sulfides; hydrogen sulfide detected during dilute mineral acid treatment supports this view.

The Riftia pachyptila tube contains chitin $20 \%$ by gravimetric analysis after boiling in $1 \mathrm{M}$ potassium hydroxide for $24 \mathrm{~h}$ ) and both tubes contain neutral

B
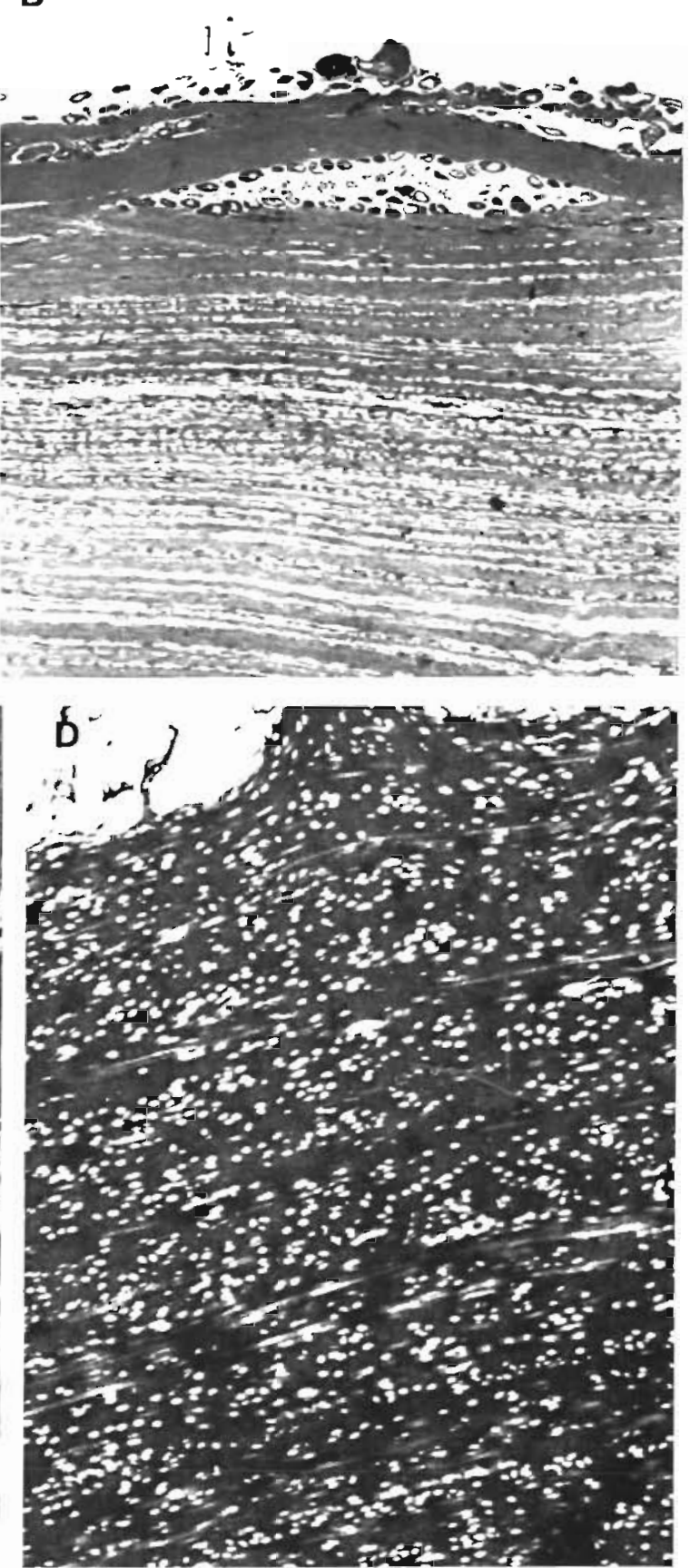

Fig. 2. Alvinella pompejana and Riftia pachyptila tubes. (A) Ultrastructural aspect of the bacteria enclosed in A. pompejana tube $(\times 2000)$. (B) Utrastructural aspect of the multilayer structure of $R$. pachyptila tube $(\times 2000)$. (C) Aspect of the tube matrix of $A$. pompejana: a row of nested areas is seen in the lower left of the micrograph, where the tube has a filamentous aspect, and small bacteria are present in the upper part $(\times 4000)$. (D) High magnification of (C) $(\times 16000)$ 
Table 1. Riftia pachyptila and Alvinella pompajana whole and ashed tube elemental compositions determined by X-ray fluorescence analysis (A) and $X$-ray microprobe analysis (B). Values are counts as a percentage of total counts

\begin{tabular}{|lrrrrrr|}
\hline \multirow{2}{*}{ Element } & \multicolumn{3}{c}{ Riftia pachyptila } & \multicolumn{3}{c|}{ Alvinella pompejana } \\
& \multicolumn{2}{c}{ Whole } & Ash & \multicolumn{2}{c|}{ Whole } & Ash \\
& $\mathrm{A}$ & $\mathrm{B}$ & & $\mathrm{A}$ & $\mathrm{B}$ & \\
\hline $\mathrm{F}$ & $\mathrm{Tr}$ & 0 & 0 & $\mathrm{Tr}$. & 0 & 0 \\
$\mathrm{Na}$ & $\mathrm{Tr}$ & 10 & 2 & 1 & 1 & 8 \\
$\mathrm{Mg}$ & $\mathrm{Tr}$ & 11 & 23 & 1 & 5 & 6 \\
$\mathrm{Al}$ & 1 & 0 & 1 & 1 & 1 & 3 \\
$\mathrm{Si}$ & 1 & 0 & 4 & 3 & 1 & 1 \\
$\mathrm{P}$ & $\mathrm{Tr}$. & - & 12 & 11 & 18 & 40 \\
$\mathrm{~S}$ & 77 & 51 & 36 & 46 & 56 & 10 \\
$\mathrm{Cl}$ & 9 & 21 & $\mathrm{Tr}$. & 7 & $\mathrm{Tr}$. & $\mathrm{Tr}$. \\
$\mathrm{K}$ & 5 & 1 & $\mathrm{Tr}$. & 4 & $\mathrm{Tr}$. & $\mathrm{Tr}$. \\
$\mathrm{Ca}$ & 5 & 5 & 18 & 20 & 14 & 22 \\
$\mathrm{Ti}$ & $\mathrm{Tr}$ & 0 & 0 & $\mathrm{Tr}$ & 0 & 0 \\
$\mathrm{Fe}$ & 1 & $\mathrm{Tr}$. & 3 & 1 & 3 & 5 \\
$\mathrm{Cu}$ & $\mathrm{Tr}$. & 0 & 0 & $\mathrm{Tr}$. & 0 & 0 \\
$\mathrm{Zn}$ & $\mathrm{Tr}$. & 0 & 0 & 4 & 1 & 4 \\
\hline
\end{tabular}

hexose, $7.5 \%$ for Alvinella pompejana and $3.2 \%$ for $R$. pachyptila. Both tubes contain protein and it is likely that this comprises the major balance of organic material. Table 2 gives amino acid analyses of the whole tubes, comparing these with other worm and pogonophore tubes. Both tubes have compositions typical of structural proteins but of different types. In $R$. pachyptila tube a high aspartate-glycine pattern is typical of mollusc shell matrix protein (Degens et al. 1967). In A. pompejana an elevated glycine and high serine content resembles beta fibroins (Lucas \& Rudall 1968). Notable in $R$. pachyptila is the high cysteine content $(10 \%)$. The serine $(25 \%)$ and glycine $(20 \%)$ contents in $A$. pompejana suggest a limited range of similar proteins. Unfortunately, SDS-PAGE of tube material treated with solubilization buffer yielded a very small trace of protein in the extracts, witnessing the stability of the material. In contrast, SDS-PAGE of $R$. pachyptila tube solubilisates suggests a multi-protein system (Fig. 3). There are numerous proteins evident, spanning the molecular weight range 120000 to 12000 , but the 2 dominant species occur at molecular weights 16500 and 12000 , respectively.

Both tube materials display considerable stability. This is both physical and chemical. Thermal transitions are small in water between 20 and $100^{\circ} \mathrm{C}$. The Alvinella pompejana tube extends by $7 \%$; a sharp shrinkage at $60^{\circ} \mathrm{C}$ compensates exactly for a $3 \%$ expansion between from 20 to $60^{\circ} \mathrm{C}$, and a final extension occurs sharply at $80^{\circ} \mathrm{C}$. The Riftia pachyptila tube shrinks overall by only $3 \%$ over the temperature range but there are several transitions; slight shrinkage between 20 and $40^{\circ} \mathrm{C}$ is compensated for by swelling up to $60^{\circ} \mathrm{C}$, and a small sharp shrinkage up to $80^{\circ} \mathrm{C}$ precedes a slight expansion with a sudden $2.5 \%$ shrinkage at $90^{\circ} \mathrm{C}$. Such complex behaviour may reflect the composite nature of the polymer. The small

Table 2. Riftia pachyptia, Alvinella pompejana and other worm tube amino acid compositions expressed as the number of individual residues per 1000 total residues

\begin{tabular}{|c|c|c|c|c|c|c|}
\hline Amino acid & R. pachyptila & A. pompejana & Serpulidd ${ }^{\mathrm{d}, \mathrm{c}}$ & Sabellariid ${ }^{b, d}$ & Eunicide & Pogonophoran \\
\hline Aspartic & 111 & 67 & 167 & 76 & 62 & 113 \\
\hline Threonine & 49 & 39 & 79 & 40 & 39 & 50 \\
\hline Serine & 75 & 250 & 52 & 192 & 43 & 87 \\
\hline Glutamic & 73 & 53 & 104 & 54 & 20 & 68 \\
\hline Proline & 58 & 14 & 42 & 39 & 81 & 63 \\
\hline Glycine & 144 & 206 & 104 & 263 & 380 & 128 \\
\hline Alanine & 78 & 118 & 76 & 83 & 46 & 57 \\
\hline Cysteine & 98 & tr & 9 & 5 & 13 & 42 \\
\hline Valine & 72 & 63 & 45 & 43 & 42 & 53 \\
\hline Methionine & 2 & 15 & 7 & 8 & 0 & 12 \\
\hline Isoleucine & 32 & 21 & 40 & 22 & 19 & 38 \\
\hline Leucine & 39 & 27 & 49 & 46 & 35 & 47 \\
\hline Tyrosine & 53 & 47 & 17 & 20 & 0 & 56 \\
\hline Phenylalanine & - & 29 & 64 & 23 & 0 & 34 \\
\hline Ornithine & 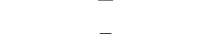 & - & 8 & - & 0 & - \\
\hline Lysine & 62 & 17 & 18 & 32 & 33 & 39 \\
\hline Histidine & 24 & 16 & 7 & 14 & 11 & 23 \\
\hline Arginine & 59 & 20 & 19 & 42 & 175 & 86 \\
\hline \multicolumn{7}{|c|}{$\begin{array}{l}\text { Average of } 3 \text { species, Hydroidas norvegicus, Eupomatus sp., Pomatoceros lamarkii } \\
\text { Average of } 4 \text { species, Sabellaria floridensis, S. kaiparaensis, Phragmatopoma lapidosa, P. moerchi } \\
\text { Mitterer } 1971 \text {, Bubel et al. } 1983 \\
\text { Hyalinoecia tubicola; new data } \\
\text { Siboqlinum sp. (Foucart et al. 1965) }\end{array}$} \\
\hline
\end{tabular}




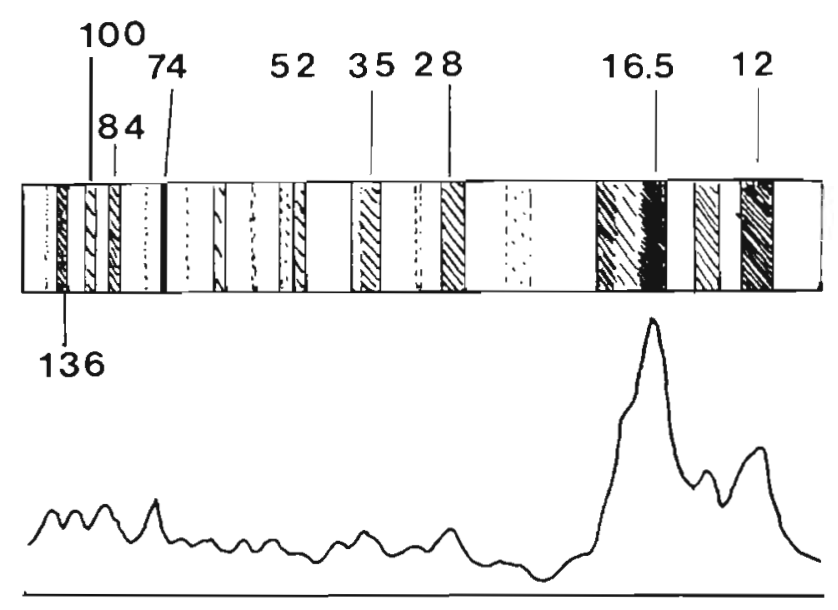

Fig. 3. Riftia pachyptila tube. Solubilized extract of the median layers SDS-PAGE electrophoresed. Densitometer scan and molecular weights indicated in kilodaltons $\times 10^{6}$

changes suggest a very stable structure; important for A. pompejana which lives at higher temperatures than R. pachyptila.

The chemical stability of the tubes is also marked. They show little bulk swelling or dissolution in mild reagents, e.g. mercaptoethanol, guanidinium hydrochloride or detergents, but the Riftia pachyptila tube does swell rapidly and partially dissolve in anhydrous formic acid. This solution contains the bulk of the chitin-proteoglycan and some protein. The residue shows slight solubility in mercaptoethanol and more so in formamide. As already mentioned, proteins from the $R$. pachyptila tube can be solubilized for SDS-PAGE. The Alvinella pompejana tube is much more stable with no appreciable solubility in formic or dichloracetic acids. A $7 \%$ swelling in $1.0 \mathrm{M}$ potassium hydroxide solubilizes $5 \%$ protein. The elemental sulfur may assist stability since after its removal $3 \%$ protein is extracted by water and then $1.5 \%$ by $4 \mathrm{M}$ guanidinium hydrochloride. Hydrochloric acid (12 M) for $30 \mathrm{~s}$ removes iron and zinc without solubilizing organic material but subsequent treatment with $1.0 \mathrm{M}$ potassium hydroxide causes $50 \%$ thickening, swelling and delamination, again with loss of $5 \%$ protein

The phylogenetic position of the Pogonophora remains disputed; the presence of an adult polymeric coelom and schizocoelic larval development indicates protosome affinity while cuticular structure, setae, opisthosomal segmentation and photoreceptor cells point to annelid relations (Hickman et al. 1984). Jones (1985) places Riftia in a new phylum, the Vestimentifera. Hence, a comparison of pogonophore tube composition relative to polychaete annelid worm tubes is justified on phylogenetic and functional grounds. Unfortunately, we have insufficient data to compare R. pachyptila compositionally with pogonophoran species from non-deep sea hydrothermal sites. More data are available for the varied tube types from polychaete worms (Mitterer 1971). Polychaete families which secrete tubes fall into 3 main types. Chaetopteridae, Sabellidae and Eunicidae secrete flexible membranous or horny uncalcified tubes; often incorporating mud or sand. Serpulidae produce calcified tubes. Fragile tubes of mucus or cementing material, incorporating sand or clay, are produced by Spionidae, Maldaniidae, Sabellaridae, Amphictenidae, Ampharetidae, Terebellidae and Nereidae. Other families produce tubes of mucus or no tube at all (Defretin 1971).

A distinct difference between the Riftia pachyptila and Alvinella pompejana tubes is that the former contains chitin while the latter does not. This is in accordance with known properties of pogonophorans compared to other polychaete tubes. The only analysis available for a pogonophoran tube is from Siboglinum sp. (Foucart et al. 1965) where the chitin content was $33 \%$, rather more than $R$. pachyptila with $20 \%$, but completely contrasting with polychaete tubes where chitin is absent.

The striking feature of polychaete tubes is their lack of morphological and chemical uniformity. Morphologically, the Riftia pachyptila tube (viewed as an

Table 3. Riftia pachyptila, Alvinella pompejana and other worm tube amino acid compositions broken down into specific types or groups. Acidic: Asp + Glu; Basic: Lys + His + Arg; Polar: Acidic + basic + Ser + Thr + Tyri Apolar: Pro + Ala + Val + Ile + Leu + Phe. Hydrophobic index calculated from data in Levitt (1976). Units as in Table 2

\begin{tabular}{|c|c|c|c|c|c|c|}
\hline & R. pachyptila & A. pompejana & $\begin{array}{l}\text { Serpulid } \\
( \pm \text { SD })\end{array}$ & $\begin{array}{c}\text { Sabellariid } \\
\qquad \pm S D)\end{array}$ & Eunicid & $\begin{array}{l}\text { Pogonophora: } \\
\text { Siboglinum sp }\end{array}$ \\
\hline Acidic & 184 & 120 & $272( \pm 71)$ & $130( \pm 32)$ & 82 & 181 \\
\hline Basic & 145 & 53 & $43( \pm 1)$ & $89( \pm 14)$ & 219 & 148 \\
\hline Polar & 506 & 509 & $463( \pm 79)$ & $470( \pm 20)$ & 384 & 522 \\
\hline Apolar & 280 & 272 & $317( \pm 55)$ & $255( \pm 21)$ & 224 & 292 \\
\hline Polar: apolar & 1.8 & 1.8 & $1.5( \pm 0.06)$ & $1.9( \pm 0.13)$ & 1.7 & 1.8 \\
\hline Hydrophobic index & -233 & 1.2 & $-223( \pm 121)$ & $-184( \pm 94)$ & -505 & -202 \\
\hline Glycine & 114 & 206 & $104( \pm 9)$ & $263( \pm 36)$ & 380 & 128 \\
\hline Tyrosine & 53 & 47 & $17( \pm 4)$ & $20\{ \pm 18\}$ & 0 & 56 \\
\hline Cysteine & 98 & $\operatorname{tr}$ & $9( \pm 10)$ & $5( \pm 2)$ & 13 & 42 \\
\hline
\end{tabular}


annelid type) is of the membranous, horny group while that of Alvinella pompejana is of the fragile class, incorporating exogenous minerals. Table 3 compares amino acid compositions of the $R$. pachyptila and $A$. pompejana tubes with those of other polychaetes and pogonophorans. Such an analysis demonstrates the inconsistency of worm-tube protein types. Acidic amino acid contents vary widely, never falling below $8 \%$ of total but rising in some serpulids to $30 \%$ of total amino acids. Likewise basic amino acid levels show wide variation. A more consistent feature is the ratio of polar to apolar amino acids which indicates a significantly polar protein character. A. pompejana is the only worm tube to show a positive hydrophobic index, suggesting that non-aqueous stabilizing interactions are favoured. Perhaps this also helps to explain the intimate association of elemental sulfur with the structure.

The most striking feature of the Riftia pachyptila tube analysis is its close correspondence to that of the pogonophoran Siboglinum sp. This coupled with the high chitin content speaks for a close affinity between the 2 species. $R$. pachyptila tube protein is also not unlike some of the other worm tube proteins. The polar:apolar ratio is high and the hydrophobic index very negative, indicating a structure likely to be strongly hydrated and with hydrogen-bonded and other polar interactions favoured. The glycine content is high in Alvinella pompejana and lower in $R$. pachyptila. High glycine contents in invertebrate structural proteiñs, coupipled with iow acidic amıno acid contents, suggest extended sheet conformations, not usually associated with calcification. The reverse situation points to more elaborate folding and also to calcification potential.

Physical and chemical stability is common in extracellular structural materials produced by invertebrates (Vincent 1982). Stability can be achieved in several ways. Simple polymers of repetitive monomer structure tend to linear conformations; these in turn tend to paracrystalline assemblies with stabilization commonly involving hydrogen-bonded and Van der Waals interchain regular interactions (Hunt \& Oates 1978). Globular proteins with high helical content also tend to self-assemble as sheets or fibres (Cohen 1966). Such materials can be further stabilized by inter- and intrachain covalent cross-links of which diverse types are now known. Elemental sulfur should be also considered with protein composition as a factor affecting the hydrophobic character and stability of the Riftia pompejana tube.

$X$-ray diffraction studies of the tubes (unpubl.) indicate a paracrystalline chitin component of the vestimentiferan tube; that of the polychaete shows no orientation at medium to high diffraction angles.
The plywood architecture of the Alvinella pompejana tube and the nested arcs series observed in oblique sections indicate a liquid crystalline-like organization (Bouligand 1971) whose type has to be analysed. Liquid crystalline-like organization has also been noted in some pogonophoran tubes where chitin is involved in the structure (Gupta \& Little 1975).

The physical and chemical stabilities of both Riftia pachyptila and Alvinella pompejana tubes point to proteins which are strongly self-interactive either via multiple weak interactions or through covalent bridging. The former may be implicated partly in $R$. pachyptila tube stabilization since the combined effects of formic acid (non-hydrolytically) and formamide cause appreciable solubilization. For A. pompejana tube no reagent causes significant solubilization; formic acid fails as a chaotropic agent and only altemate extremes of $\mathrm{pH}$ bring about hydrophilic swelling. This suggests that ionic interactions, probably with inorganic components, have some stabilizing influence but that covalency is a major factor. There is insufficient cysteine in A. pompejana protein to explain stability through disulfide bridging. In $R$. pachyptila tube a high cysteine content might point to disulfide as being an important structural determinant. However, this cannot account for residual stability after formic acid treatment since disulfide breaking agents produce very little solubilization.

Both dwelling tube types have high chemical stability, an aspect accentuated in Alvinella pompejana. This may be related to location, as this worm lives close to the chimney in a region of high temperature and exotic chemistry.

Fossilized worm tubes have been found in areas of ancient extinct hydrothermal vent activity (Haymon et al. 1984, Oudin \& Constantinou 1984, Banks 1985). Such tubes are coated with concentric layers of amorphous silica intercalated with thin sulfide laminae. Probably the silica is formed by replacement of organic material during fossilization, but the hypothesis of biogenic origin for sulfide laminae is corroborated by the presence of bacterial growth layers and elemental sulfur inside the tube in Alvinella pompejana tubes. These results may give some indication about tube type, allowing fossilized vestimentiferan tubes to be distinguished from polychaetous ones.

Acknowledgements. The authors gratefully acknowledge the chief scientist of the Biocyarise cruise, Daniel Desbruyères, and M. C. Laine for technical assistance. Dr. R. Macdonald and Mr. J. Bowman of the Department of Environmental Sciences and Dr. S. Breuer of Chemistry Department at Lancaster University are thanked for help with X-ray fluorescence and mass spectral analyses respectively. 


\section{LITERATURE CITED}

Arp, J. A., Childress, J. J. (1981). Blood function in the hydrothermal vent vestimentiferan tube worm. Science, N.Y 213: $342-344$

Banks, D. A. (1985). A fossil hydrothermal worm assemblage from the Tynagh lead-zinc deposit in Iceland. Nature, Lond. 313: 127-129

Barker, S. A., Cruickshank, C. N. D., Morris, J. H. (1963). Structure of a galactomannan-peptide allergen from Trichophyton mantagrophytes. Biochim. biophys. Acta 74 : 239-246

Bouligand, Y. (1971). Les orientations fibrillaires dans le squelette des arthropodes. 1. L'exemple des crabes, l'arrangement torsadée des strates. J. Microscopie 11: $441-472$

Bubel, A., Stephens, R. M., Fenn, R. H., Fieth, P. (1983). An electron microscope, $\mathrm{X}$-ray diffraction and amino acid analysis study of the opercular plate and habitation tube of Pomatoceros lamarkii quatrefages (Polychaeta: Serpulidae). Comp. Biochem. Physiol. 74 B: 837-850

Cavanaugh, C. M., Gardiner, S. L., Jones, M. L., Jannasch, H. W., Waterbury, S. B. (1981). Prokaryotic cells in the hydrothermal vent tube worm Riftia pachyptila Jones: possible chemoautotrophic symbionts. Science, N.Y 213: 340-341

Cohen, C. (1966). Architecture of the alpha-class of fibrous proteins. In: Hayashi, T., Szent-Gyorgyi, A. G. (ed.) Molecular architecture in cell physiology. Prentice Hall, New Jersey, p. 169-190

Defretin, R. (1971). The tubes of polychaete annelids. In: Florkin, M., Stotz, E. H. (ed.) Comprehensive biochemistry. Elsevier, Amsterdam, p. 713-747

Degens, E. T., Spencer, D. W., Parker, R. H. (1967). Paleobiochemistry of molluscan shell proteins. Comp. Biochem. Physiol. 20: 553-579

Desbruyères, D., Gaill, F., Laubier, L., Prieur, D., Rau, G. H. (1983). Unusual nutrition of the 'Pompeii worm' Alvinella pompejana (polychaetous annelid) from a hydrothermal vent environment: SEM, TEM, ${ }^{13} \mathrm{C}$ and ${ }^{15} \mathrm{~N}$ evidence. Mar. Biol. 75: 201-205

Desbruyères, D., Gaill, F., Laubier, L., Fouquet, Y. (1985). Polychaetous annelids from hydrothermal vent ecosystems: an ecological overview. Bull. Biol. Soc. Wash. 6: 103-116

Foucart, M. F., Briteaux-Grégoire, S., Jeuniaux, C. (1965). Composition chimique du tube d'un pogonophore (Sibo- glinum sp.) et des formations squelletiques de deux ptérobranches. Sarsia 20: 35-41

Gaill, F., Desbruyères, D., Prieur, D., Gourret, J. P. (1984). Mise en évidence de communautes bactériennes épibiontes du 'Ver de Pompei' (Alvinella pompejana). C.r. hebd. Séanc. Acad. Sci., Paris 298: 553-558

Gupta, B. L., Little, C. (1975). Ultrastructure, phylogeny and Pogonophora. Zool. Syst. Evol. Sanders 2: 45-64

Haymon, R. M. Koski, R. A., Sinclair, R. A. (1984). Fossils of hydrothermal vent worms from cretaceous sulfide area of the Samail Ophiolite Oman. Science, N.Y. 223: 1407-1409

Hickman, C. P., Roberts, L. S., Hickman, F. M. (1984). Integrated principles of zoology. Times Mirror/Mosby College Publishing, St. Louis

Hunt, S., Oates, K. (1978). Fine structure and molecular organisation of the periostracum in a gastropod mollusc Buccinum undatum L. and its relation to similar structural protein systems in other invertebrates. Phil. Trans. R. Soc., Ser. B. 283: 417-463

Hunt, S., Nixon, M. (1981). A comparative study of protein composition in the chitin-protein complexes of the beak, pen, sucker disc, radula and oesophageal cuticle of cephalopods. Comp. Biochem. Physiol. 68 B: 535-546

Jones, M. L. (1985). The hydrothermal vents of the Eastern Pacific: an overview. Bull. Biol. Soc. Wash. 6: 117-158

Juniper, S. K., Thompson, J. A., Calvert, S. E. (in press). Accumulation of minerals and trace elements in biogenic mucus at hydrothermal vents. Deep Sea Res.

Levitt, L. (1976). A simplified representation of protein conformations for rapid simulation of protein folding. J. molec. Biol. 104: 59-108

Lucas, F., Rudall, K. M. (1968). Extracellular fibrous proteins: the silks. In: Florkin, M., Stotz, E. H. (ed.) Comprehensive biochemistry. Elsevier, Amsterdam, p. 475-558

Mitterer, R. M. (1971). Comparative amino acid composition of calcified and non-calcified polychaete worm tubes. Comp. Biochem. Physiol. 38 B: 405-409

Oudin, E., Constantinou, G. (1984). Black smoker chimney fragments in lypous sulfide deposits. Nature, Lond. 308 : $349-351$

Vetter, R. D. (1985). Elemental sulfur in the gills of three species of clams containing chemoautotrophic bacteria: a possible inorganic energy storage compound. Mar. Biol. 88: $33-42$

Vincent, J. F. V. (1982). Structural biomaterials. MacMillan, London 